\title{
Buffered lidocaine and bupivacaine mixture - the ideal local anesthetic solution?
}

\author{
Corliss A Best HBA(Kin) ${ }^{1}$, Alyssa A Best BHSc${ }^{2}$, Timothy J Best MD MSc ${ }^{1}$, Danielle A Hamilton MD BSc ${ }^{1}$
}

CA Best, AA Best, TJ Best, DA Hamilton. Buffered lidocaine and bupivacaine mixture - the ideal local anesthetic solution? Plast Surg 2015;23(2):87-90.

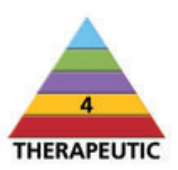

The use of injectable local anesthetic solutions to facilitate pain-free surgery is an integral component of many procedures performed by the plastic surgeon. In many instances, a solution that has both rapid onset and prolonged duration of analgesia is optimal. A combination of lidocaine and bupivacaine, plain or with epinephrine, is readily available in most Canadian health care settings where such procedures are performed, and fulfills these criteria. However, commercially available solutions of both medications are acidic and cause a burning sensation on injection. Buffering to neutral $\mathrm{pH}$ with sodium bicarbonate is a practical method to mitigate the burning sensation, and has the added benefit of increasing the fraction of nonionized lipid soluble drug available. The authors report on the proportions of the three drugs to yield a neutral $\mathrm{pH}$, and the results of an initial survey regarding the use of the combined solution with epinephrine in hand surgery.

\section{Un mélange tampon de lidocaïne et de bupivacaïne, l'anesthésique local idéal?}

L'injection d'anesthésiques injectables locaux pour favoriser une opération sans douleur fait partie intégrante des nombreuses interventions réalisées par le plasticien. Dans bien des cas, une solution analgésique à action longue et rapide est optimale. Une bithérapie de lidocaïne et de bupivacaïne, seule ou accompagnée d'adrénaline, disponible dans la plupart des milieux de santé canadiens où de telles interventions sont effectuées, respecte ce critère. Les solutions commerciales de ces deux médicaments sont toutefois acides et provoquent une sensation de brûlure à l'injection. L'utilisation d'un tampon de bicarbonate de sodium pour obtenir un $\mathrm{pH}$ neutre est pratique pour limiter la sensation de brûlure et a l'avantage supplémentaire d'accroître la fraction de médicament liposoluble non ionisé disponible. Les auteurs rendent compte des proportions des trois médicaments nécessaires pour obtenir un $\mathrm{pH}$ neutre et des résultats d'un sondage initial sur l'utilisation de la bithérapie combinée à l'adrénaline pour la chirurgie de la main.

Key Words: Buffering; Bupivacaine; Lidocaine

L essening the pain of injection of local anesthetic (LA) is a desirable objective $(1,2)$. Commercially available solutions of lidocaine are acidic, which causes pain upon injection $(3,4)$. The merit of buffering lidocaine solutions to neutral $\mathrm{pH}$ as a method to eliminate this pain has been clinically advocated for decades (5-13). A 2010 Cochrane review of double-blinded randomized controlled trials that compared $\mathrm{pH}$-adjusted lidocaine with unadjusted lidocaine concluded that buffering to neutral $\mathrm{pH}$ decreased pain on injection, and augmented patient comfort and satisfaction (14).

Lidocaine has a limited duration of action, which is sometimes desired in an LA but for many procedures is less than ideal. Bupivacaine has a much longer duration of action; however, due to its slow onset, it is not an ideal sole agent for procedural analgesia in most situations (15). The slow onset also results in a more painful injection when used as a sole agent because one cannot practically 'freeze ahead of the needle'; the recipient, therefore, feels the needle tip traversing throughout the tissues being infiltrated, a painful experience $(1,2)$. In addition, bupivacaine, similar to lidocaine, is commercially supplied as an acidic solution, especially those prepared with epinephrine; the acidity contributes to injection pain.

However, combining these two amide LA agents in one syringe offers the clinician and patient the best effects of both drugs: the very rapid onset of lidocaine and the prolonged duration of bupivacaine. The present study aimed to investigate the amount of sodium bicarbonate required to neutralize the $\mathrm{pH}$ of these solutions, plain and with epinephrine, and to document some of the clinical properties of the use of these solutions in hand surgery.

\section{METHODS}

Part 1: laboratory work

Thirteen different solutions of lidocaine, bupivacaine and combinations of each, both plain and with epinephrine, were tested. The authors used $20 \mathrm{~mL}$ single-use vials available at their institution because they do not contain preservatives that have been shown to affect the precipitation characteristics of LA solutions (16).

Twenty millitres of each of the solutions were placed in clean $50 \mathrm{~mL}$ clear plastic containers at room temperature (approximately $21^{\circ} \mathrm{C}$ ); $8.4 \%(1 \mathrm{mEq} / \mathrm{mL})$ sodium bicarbonate $\left(\mathrm{NaHCO}_{3}\right)$ at room temperature was added by micropipette to the lidocaine solutions in $200 \mu \mathrm{L}$ increments (to a maximum of $3 \mathrm{~mL}$ ) and to the bupivacaine solutions in $20 \mu \mathrm{L}$ increments (to a maximum of $0.2 \mathrm{~mL}$ ). After the addition of each increment, solutions were manually shaken to ensure thorough mixing. They were then inspected for macroscopic precipitate formation against both white and black backgrounds. Measures were repeated three times for each solution and the results were averaged.

$\mathrm{pH}$ measurement: The $\mathrm{pH}$ levels of all solutions were measured both before and after each addition of $\mathrm{NaHCO}_{3}$ using a $\mathrm{pH}$ meter (Accumet AB15, Fisher Scientific, Canada) calibrated to $\mathrm{pH} 4.00,7.00$ and 10.00 with certified buffer solutions from the manufacturer. The $\mathrm{pH}$ meter was standardized between each solution. Electrodes were rinsed with distilled water and blotted dry between each $\mathrm{pH}$ measurement to minimize the chance for contamination. Three samples of each solution were tested and the mean $\mathrm{pH}$ reported.

Optimal volume of $\mathrm{NaHCO}_{3}$ required/ratio by volume/increase in nonionized fraction: The optimal volume of $\mathrm{NaHCO}_{3}$ for each LA solution was determined as being the volume of $\mathrm{NaHCO}_{3}$ needed to achieve near neutral $\mathrm{pH}$ without any macroscopic precipitate. Ratio by volume was then calculated: total volume of LA divided by optimal volume of buffer added. Relative increase in the nonionized fraction was determined by calculating ratio of ionized to nonionized ratio $(\mathrm{LH}+\mathrm{L})$ at both initial $\mathrm{pH}$ and final $\mathrm{pH}$ using the HendersonHasselbalch equation:

$$
\begin{aligned}
&\left(\left[10^{\mathrm{pKa}-\mathrm{pH}}\right.\right.=\text { ionized/nonionized })_{\text {at initial } \mathrm{pH}} / \\
&\left.\left.\left(10^{\mathrm{pKa}-\mathrm{pH}}=\text { ionized/nonionized }\right)_{\text {at final }} \mathrm{pH}\right]\right)
\end{aligned}
$$

${ }^{1}$ Northern Ontario School of Medicine, Sault Ste Marie, Ontario; ${ }^{2}$ London School of Economics and Political Science, London, United Kingdom

Correspondence: Dr Timothy J Best, Northern Ontario School of Medicine, 504-421 Bay Street, Sault Ste Marie, Ontario P6A 1 X3.

Telephone 705-256-6012,fax 705-256-7228,e-mail tjb@bestsurg.com 
TABLE 1

Solutions tested

\begin{tabular}{|c|c|c|c|c|c|c|}
\hline \multirow[b]{2}{*}{ Solution } & \multicolumn{2}{|c|}{$\mathrm{pH}$, mean $\pm \mathrm{SD}$} & \multirow{2}{*}{$\begin{array}{l}\text { Optimal* volume of } \\
8.4 \% \mathrm{NaHCO}_{3}, \mu \mathrm{L}\end{array}$} & \multirow{2}{*}{$\begin{array}{c}\text { Ratio } \\
\text { by volume }\end{array}$} & \multirow{2}{*}{$\begin{array}{l}\text { Relative increase in } \\
\text { nonionized fraction }\end{array}$} & \multirow{2}{*}{$\begin{array}{l}\text { LA: } \mathrm{NaHCO}_{3} \\
\text { (for } 10 \mathrm{~mL} \text { ) }\end{array}$} \\
\hline & Initial & Final & & & & \\
\hline 1\% Lidocaine & $6.65 \pm 0.015$ & $7.56 \pm 0.015$ & 2000 & $10: 1$ & 8.1 & 9.09:0.91 \\
\hline 1\% Lidocaine/epinephrine & $4.05 \pm 0.017$ & $7.66 \pm 0.021$ & 2200 & $9: 1$ & 4073.8 & $9.00: 1.00$ \\
\hline 2\% Lidocaine/epinephrine & $4.23 \pm 0.08$ & $7.20 \pm 0.02$ & 1200 & $17: 1$ & 933.3 & $9.71: 0.29$ \\
\hline 0.25\% Bupivacaine & $5.83 \pm 0.074$ & $7.14 \pm 0.032$ & 60 & 333:1 & 20.4 & $9.97: 0.03$ \\
\hline 0.50\% Bupivacaine/epinephrine & $4.26 \pm 0.14$ & $6.53 \pm 0.04$ & 100 & $200: 1$ & 186.2 & $9.95: 0.05$ \\
\hline Lidocaine/bupivacaine $^{\dagger}$ & $6.38 \pm 0.46$ & $7.11 \pm 0.04$ & 400 & $50: 1$ & 5.4 & $9.80: 0.20$ \\
\hline Lidocaine/bupivacaine/epinephrine & $4.23 \pm 0.12$ & $7.08 \pm 0.05$ & 800 & $25: 1$ & 707.9 & $9.62: 0.38$ \\
\hline
\end{tabular}

${ }^{*}$ Maximum volume of $8.4 \%$ sodium bicarbonate $\left(\mathrm{NaHCO}_{3}\right)$ added without causing precipitation; ${ }^{+} 2 \%$ lidocaine and $0.5 \%$ bupivacaine in a $1: 1$ ratio; ${ }^{\ddagger} 2 \%$ lidocaine with 1:100,000 epinephrine and 0.5\% bupivacaine with 1:200,000 epinephrine in a 1:1 ratio. LA Local anesthetic

\section{Part 2: clinical survey}

A series of adult patients undergoing either carpal tunnel release surgery or trigger digit surgery were surveyed. LA for all surgeries was a $50 / 50$ solution of $0.5 \%$ bupivacaine with $1: 200,000$ epinephrine/2\% lidocaine with 1:100,00 epinephrine buffered with $8.4 \% \mathrm{NaHCO}_{3}$ (Table 1). The time of administration was noted for each patient. They were asked to make a note of when they perceived pain at their surgical site, and were followed-up the next day with a telephone call to record their answer.

\section{Part 1: laboratory work}

\section{RESULTS}

Effect of alkalinization on $\mathrm{pH}$ and precipitation: The mean initial $\mathrm{pH}$ of the five plain solutions was 5.55 to 6.65 . Mean initial $\mathrm{pH}$ of the five solutions with epinephrine was lower (4.05 to 4.40) (Table 1). Adding $8.4 \% \mathrm{NaHCO}_{3}$ in volume increments of $200 \mu \mathrm{L}$ or $20 \mu \mathrm{L}$, depending on the solution studied, increased all $\mathrm{pH}$ measures. The final $\mathrm{pH}$ ranges at which no precipitation occurred were near neutral, with a range of 6.53 to 7.66 (Table 1). Eventually, as more $\mathrm{NaHCO}_{3}$ was added, macroscopic precipitation was observed in all solutions.

LA to $\mathrm{NaHCO}_{3}$ volume ratios: The authors found that the LA to $\mathrm{NaHCO}_{3}$ volume ratios (ratio by volume) required to increase the $\mathrm{pH}$ of the LA solutions without precipitation ranged from 9:1 to 500:1 (Table 1). All of the LA solutions with epinephrine required a lower ratio of LA to buffer (or more buffer per unit of LA).

Effect of alkalinization on the relative increase in nonionized fraction: After alkalinization, the nonionized fraction of lidocaine and bupivacaine increased in all LA solutions tested. The highest relative increases in the nonionized fraction of both lidocaine and bupivacaine were observed in the five solutions containing epinephrine (1\% lidocaine/epinephrine, 2\% lidocaine/epinephrine, $0.25 \%$ bupivacaine/ epinephrine, $0.5 \%$ bupivacaine/epinephrine and lidocaine/bupivacaine/epinephrine). Only marginal increases in the nonionized fraction were observed in the corresponding plain solutions $(1 \%$ lidocaine, $2 \%$ lidocaine, $0.25 \%$ bupivacaine, $0.5 \%$ bupivacaine, and lidocaine/bupivacaine) (Table 1).

\section{Part 2: clinical survey}

A total of 20 consecutive patients were surveyed ( 10 female, 10 male). The mean $( \pm$ SD) duration of anesthesia reported was $11 \mathrm{~h}: 18 \pm 215.5 \mathrm{~min}$ with a range of $5 \mathrm{~h}$ and $17 \mathrm{~h}: 35 \mathrm{~min}$. There was no significant difference between female and male patients.

\section{DISCUSSION}

There is no ideal LA solution for all applications; however, we have found the buffered combination solution of lidocaine and bupivacaine with epinephrine to be extremely versatile in plastic surgery. There are at least two theoretical advantages of neutral buffered versus acidic $\mathrm{pH}$ solutions for LA injection: less painful infiltration and faster onset of anesthesia. Infiltration of nonbuffered acidic local anesthesia causes more pain than the injection of neutral buffered solutions (14). Neutralizing the solutions results in fewer hydrogen ions being injected - ions that appear to be responsible for the burning sensation reported by patients receiving acidic injections.

In addition, tissue anesthesia onsets faster when neutral solutions are injected. Compared with acidic solutions 'out of the bottle', more molecules of the drug are in the nonionized state in neutralized solutions. LA molecules must be in the nonionized state to penetrate both nerve cell sheaths and neural membranes (15). Once inside the cell, the nonionized drug gains a hydrogen ion, and this ionized form is responsible for the neural blockade. LAs are weak bases, and the relative proportion of each form of the drug depends on the solution $\mathrm{pH}$ and the drug's $\mathrm{pKa}$ ( $\mathrm{pH}$ at which the nonionized and ionized fractions are at equilibrium). The relationship between $\mathrm{pH}$ and $\mathrm{pKa}$ is described by the Henderson-Hasselbalch equation:

$$
\mathrm{pKa}-\mathrm{pH}=\log (\mathrm{LH}+) /(\mathrm{L})
$$

in which $\mathrm{LH}+$ denotes the ionized fraction and $\mathrm{L}$ represents the nonionized fraction $(15,17)$. Hence, raising the $\mathrm{pH}$ closer to $\mathrm{pKa}$ increases the fraction of the drug in the nonionized form, increasing the proportion of the administered dose that can enter neurons. This hastens anesthesia onset, reduces pain transmission and, thus, lowers pain perception on LA infiltration into tissues $(3,5,8,15,18)$. Alkalinization also increases intracellular concentration of carbon dioxide, which effectively decreases intracellular $\mathrm{pH}$. In more acidic intracellular $\mathrm{pH}$, LAs exist more so in the ionized base form, actively blocking nerve cell sodium channels, thus preventing depolarization and the propagation of action potentials $(15,18)$. The buffering effect on intracellular $\mathrm{pH}$ may, thus, also contribute to the more rapid onset of anesthesia reported with alkalinized solutions.

\section{Epinephrine-containing LA solutions}

The use of epinephrine-containing LAs in all body parts has a long, safe history in plastic surgery. Lalonde and Martin (19) and others $(20,21)$ have provided a tremendously positive service to practitioners and the patients we serve by their work to debunk the traditional teaching of avoidance epinephrine-containing LAs in digits. It is the senior author's (TJB) opinion, that this can be safely extended to all 'end-artery' body parts - the nose, ears, penis, etc.

In the present study, we confirmed that LA solutions containing epinephrine were more acidic than their plain counterparts, consistent with previous reports $(3,5,18)$. In addition to the lower initial $\mathrm{pH}$, various additives, such as sodium metabisulphite and $\mathrm{pH}$ adjusters such as hydrochloric acid and sodium hydroxide contribute buffering capacity $(16,18)$. Sodium metabisulphite is a strong antioxidant that 
combines with epinephrine to form an inactive epinephrine sulfonate at $\mathrm{pH}>4$, and is added to prevent the oxidation of epinephrine $(7,22)$. All of the commercially prepared LAs with epinephrine required a greater amount of bicarbonate buffer to raise $\mathrm{pH}$ to near neutral without precipitation, and had the highest relative increase in the nonionized fraction with sodium bicarbonate buffering. Thus, there is greater clinical benefit of buffering these solutions compared with their plain or freshly prepared counterparts.

\section{SUMMARY}

The combined solution of 2\% lidocaine with 1:100,000 epinephrine and $0.5 \%$ bupivacaine with $1: 200,000$ epinephrine in a $1: 1$ ratio, buffered with $\mathrm{NaHCO}_{3}$, may be the ideal LA solution for practitioners to use in many clinical applications. A practical clinical application of the laboratory investigations presented in the present study is as follows:

- $10 \mathrm{~mL}$ syringe;

- $4.5 \mathrm{~mL}$ of 2\% lidocaine with 1:100,000 epinephrine;

- $4.5 \mathrm{~mL}$ of $0.5 \%$ bupivacaine with 1:200,000 epinephrine; and

- $0.4 \mathrm{~mL}$ of $8.4 \% \mathrm{NaHCO}_{3}$.

This yields $9.4 \mathrm{~mL}$ of a combined solution, useful for many clinical applications. Obviously, volumes of each are halved for a $5 \mathrm{~mL}$ syringe, etc. This solution contains $0.96 \%$ lidocaine, $0.24 \%$ bupivacaine and 1:156,666 epinephrine. In our survey using this solution for 20 consecutive patients in hand clinic, a mean of $11 \mathrm{~h}: 18 \mathrm{~min}$ of anesthesia was reported.

\section{Areas for further work}

We did not investigate the chemical stability of epinephrine in buffered solutions over time. There is little work that addresses stability, particularly for the alkalinized lidocaine/bupivacaine combination, with only one published article reporting on the stability of epinephrine in such solutions (11). It is well documented that the chemical stability of epinephrine decreases significantly following alkalinization because increasing the $\mathrm{pH}$ of LA solutions favours the oxidation of epinephrine $(3,8)$. What is unclear is the chemical stability of epinephrine in buffered solutions for prolonged periods of time (23-29). Until stability issues are better explained, we recommend buffering solutions containing epinephrine just before use.

Second, the theoretical advantage of more rapid anesthesia onset with buffered LA solutions has not been shown in our model of a combined lidocaine/bupivacaine solution. The magnitude and clinical significance of this effect requires investigation.

Third, our pilot survey involving 20 patients receiving the combined solution in hand surgery was just that, a pilot survey. A rigorous blinded study with appropriate statistical power would be ideal to more fully investigate the clinical characteristics of this solution.

The fourth area of investigation was in regard to epinephrine concentration. Because bupivacaine is only commercially available in Canada with 1:200,000 epinephrine, our final solution contains 1:156,666 epinephrine. It is not clear whether this is sufficiently concentrated for all applications of tourniquet-free hand surgery, compared with the published data using 1:100,000 epinephrine containing lidocaine. We have performed the laboratory work on plain solutions of lidocaine and bupivacaine with freshly added epinephrine (not reported), but not the clinical work. The emphasis in the present study was to investigate commercially prepared epinephrine containing LA solutions because we believe this will appeal to the widest audience of clinicians.

ACKNOWLEDGEMENTS: The authors thank Dr Rian Schwarz and staff at the Great Lakes Forestry Centre, Sault Ste Marie, Ontario, for providing the laboratory equipment and technical support for this study. They also thank Mrs Dawn Jennings, Pharmacy Manager at the Sault Area Hospital, and her staff for their assistance.

DISCLOSURES: The authors have no financial disclosures or conflicts of interest to declare.

\section{REFERENCES}

1. Strazar R, Lalonde D. Minimizing injection pain in local anesthesia. CMAJ 2012;184:2016.

2. Strazar AR, Leynes PG, Lalonde DH. Minimizing the pain of local anesthesia injection. Plast Reconstr Surg 2013;132:675-84.

3. Morris RW, Whish DKM. A controlled trial of pain on skin infiltration with local anesthetics. Anaesth Intens Care 1994;12:113-4.

4. Davies RJ. Buffering the pain of local anaesthetics: A systematic review. Emerg Med 2003;15:81-8.

5. Bartfield JM, Gennis P, Barbera J, Breuer B, Gallagher EJ. Buffered versus plain lidocaine as a local anesthetic for simple laceration repair. Ann Emerg Med 1990;19:1387-9.

6. Jones JS, Plzak C, Wynn BN, Martin S. Effect of temperature and $\mathrm{pH}$ adjustment of bupivacaine for intradermal anesthesia. Am J Emerg Med 1998;16:117-20.

7. Cheney PR, Molzen G, Tandberg D. The effect of $\mathrm{pH}$ buffering on reducing the pain associated with subcutaneous infiltration of bupivacaine. Am J Emerg Med 1991;9:147-8.

8. Orlinsky M, Hudson C, Chan L, Deslauriers R. Pain comparison of unbuffered versus buffered lidocaine in local wound infiltration. J Emerg Med 1992;10:411-5.

9. Burns CA, Ferris G, Feng C, Cooper JZ, Brown MD. Decreasing the pain of local anesthesia: A prospective double-blind comparison of buffered, premixed 1\% lidocaine with epinephrine versus 1\% lidocaine freshly mixed with epinephrine. J Am Acad Dermatol 2006;54:128-31.

10. Morris RW, McKay W, Muschlin P. Comparison of pain associated with intradermal and subcutaneous infiltration with various local anesthetic solutions. Anesth Analg 1987;66:1180-2.

11. Masters JE. Randomised control trial of $\mathrm{pH}$ buffered lignocaine with adrenaline in outpatient operations. Br J Plas Surg 1998;51:385-7.

12. Welch MN. Czyz CN. Kalwerisky K. Holck DE. Mihora LD. Double-blind, bilateral pain comparison with simultaneous injection of $2 \%$ lidocaine versus buffered $2 \%$ lidocaine for periocular anesthesia. Ophthalmology 2012;119:2048-52.

13. Vossinakis IC, Stavroulaki P, Paleochorlidis I, Badras LS. Reducing the pain associated with local anaesthetic infiltration for open carpal tunnel decompression. J Hand Surg (Br) 2004;29:399-401.

14. Cepeda MS, Tzortzopoulou A, Thackrey M, Hudcova J, Arora Gandhi P, Schumann R. Adjusting the $\mathrm{pH}$ of lidocaine for reducing pain on injection. Cochrane Review 2012;7:149-215.

15. Morgan GE, Mikhail MS, Murray MJ. Clinical Anesthesiology, 4th ed. USA: Lange Medical Books/McGraw-Hill; 2006:263-75.

16. Ikuta PR, Vasireddy AR, Raza SM, Winnie AP, Durrani Z, Masters RW. $\mathrm{pH}$ adjustment schedule for the amide local anesthetics. Reg Anesth 1989;14:229-35.

17. Brunton LL, Lazo JJ, Parker KJ. Goodman \& Gilman's The Pharmacological Basis of Therapeutics, 11th edn. USA: McGraw-Hill; 2006:369-86.

18. Milner QJ, Guard BC, Allen JG. Alkalinization of amide local anaesthetics by addition of $1 \%$ sodium bicarbonate solution. Eur J Anaesthesiol 2000;17:38-42.

19. Lalonde D, Martin A. Epinephrine in local anesthesia in finger and hand surgery: the case for wide-awake anesthesia. J Am Acad Orthop Surg 2013;21:443-7.

20. Denkler KA. A comprehensive review of epinephrine in the finger: To do or not to do. Plast Reconstr Surg 2001;108:114-24.

21. Mann T, Hammert WC. Epinephrine and hand surgery. J Hand Surg Am 2012;37:1254-6.

22. Russel GB, Graybeal JM, Strout JC. Titration of $\mathrm{pH}$ and $\mathrm{CO}_{2}$ partial pressure in local anesthetic agents. Anesthesiology 1990;73:A834.

23. Trissel LA. Handbook on Injectable Drugs, 14th edn. Bethesda: American Society of Health-System Pharmacists Inc; 2007:225-8, 619-26,1001-12.

24. Gershon RY, Mokriski BK, Matjasko MJ. Intradermal anesthesia and comparison of intravenous catheter gauge. Anesth Analg 1991;469-70.

25. Palmon SC, Lloyd AT, Kirsch JR. The effect of needle gauge and lidocaine $\mathrm{pH}$ on pain during intradermal injection. Anesth Analg 1998;86:379-81. 


\section{Best et al}

26. Robinson J, Fernando R, Sun Wai WY, Reynolds F. Chemical stability of bupivacaine, lidocaine and epinephrine in $\mathrm{pH}$-adjusted solutions. Anaesthesia 2000;55:853-8.

27. Bonhomme L, Postaire E, Touratier S, Benhamou D, Martre-Sauvageon H, Preaux N. Chemical stability of lignocaine (lidocaine) and adrenaline (epinephrine) in $\mathrm{pH}$-adjusted parenteral solutions. J Clin Pharmacol 1988;13:257-61.
28. Bonhomme L, Benhamou D, Jebri M, et al. Chemical stability of bupivacaine in $\mathrm{pH}$-adjusted solutions. Anaesthesiology 1988;68:754-6.

29. Bonhomme L, Benhamou D, Comoy E, Preaux N. Stability of adrenaline in $\mathrm{pH}$-adjusted solutions of local anesthetics. J Pharm Biomed Anal 1991;9:497-9. 